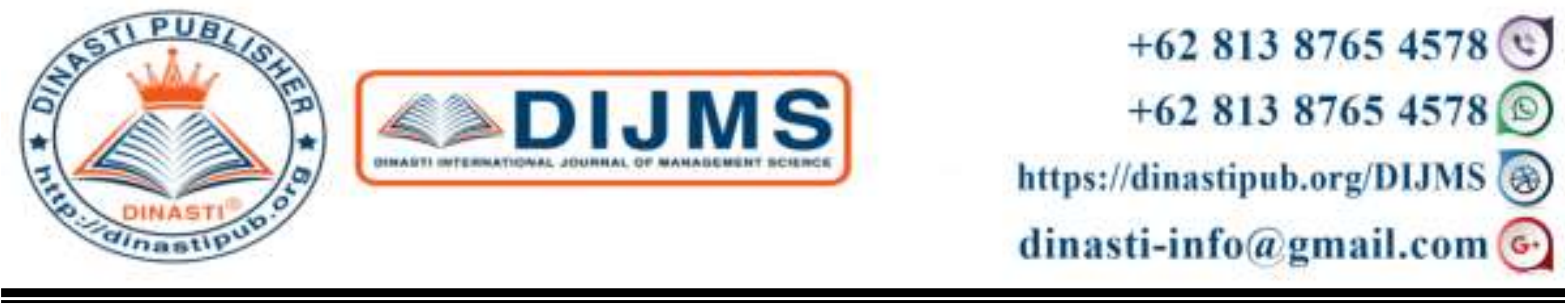

\title{
POLITICAL MARKETING IN THE ELECTION FOR GOVERNOR IN THIS DIGITAL AGE
}

\section{Reynold William $^{1)}$, Nur Endah Retno Wuryandari ${ }^{2)}$}

1) 2) Universitas Mercu Buana, Jakarta, Indonesia

\begin{tabular}{|c|c|}
\hline $\begin{array}{l}\text { ARTICLE INFORMATION } \\
\text { Received: } 19^{\text {th }} \text { April } 2020 \\
\text { Revised: } 25^{\text {th }} \text { April } 2020 \\
\text { Issued: } 14^{\text {th }} \text { May } 2020 \\
\text { Corresponding author: } \\
\text { Diana } \\
\text { E-mail: } \\
\text { reynoldwilliam.umb9@ gmail.com } \\
\text { nurendah.retno@mercubuana.ac.id } \\
\end{array}$ & $\begin{array}{l}\text { Abstract: After reformation era, there is a very } \\
\text { significant shift towards the political life in Indonesia. } \\
\text { So politicians and political parties need to redesign } \\
\text { competing strategies to win political competition. The } \\
\text { purpose of this study is to find out whether the } \\
\text { Personal Branding, Political Marketing, Politic of } \\
\text { Identity and Social Media have an influence on the } \\
\text { decision of the community's option. The unit of } \\
\text { analysis which been studied was the individuals, they } \\
\text { are the individuals who had taken part in the general } \\
\text { election of the West Java election. There are } 216 \\
\text { respondents with dissemination in } 5 \text { cities (Bekasi, } \\
\text { Bandung, Tasikmalaya, Bogor, Depok) and } 1 \text { district } \\
\text { (Garut). The result, Political Marketing and Politic of } \\
\text { Identity have a positive and significant effect on the } \\
\text { decision of the communities. Personal Branding and } \\
\text { Social Media have a positive but not significant effect } \\
\text { on the decision to vote. } \\
\text { Keywords: Personal Branding, Political Marketing, } \\
\text { Politic of Identity, Social Media, Decision to vote. }\end{array}$ \\
\hline
\end{tabular}

\section{INTRODUCTION}

Once globalization era emerged, advances in information and communication technology, made so many things that form new patterns of political interaction. Currently the method used in politics must also be adjusted and in line with the changes that are happening right now. The political world needs new approaches to be in line with the changing era (Firmanzah, 2008).

Legislative elections must be held directly, publicly, freely, confidentially, just and fair. This is in line with the democratic principle of "from the people, by the people, and for the people". This principle is also in line with what is mandated in the 1945 Constitution of the Republic of Indonesia article 1 paragraph 2. The General Election Commission has 
decided that the simultaneous regional elections in 2018 will be held on June 27, 2018 in 171 regions consisting of 13 Provinces, 39 Cities and 115 counties in Indonesia.

Legally the General Election Commission of West Java Province, held a plenary meeting in the KPU Hall, Jalan Garut, Bandung, West Java on Monday, February 12, 2018. Establishing the four Candidate Pairs (Paslon) Governor and Deputy Governor who will compete in the West Java 2018 are as follows:

Table 1.

Data Report of West Java Governor and Deputy Governor Candidates in 2018

\begin{tabular}{|c|c|c|c|c|c|}
\hline No & Election Type & $\begin{array}{l}\text { Governor } \\
\text { Candidate }\end{array}$ & $\begin{array}{c}\text { Deputy } \\
\text { Governor } \\
\text { Candidate }\end{array}$ & $\begin{array}{c}\text { The Supporting } \\
\text { Party }\end{array}$ & $\begin{array}{c}\text { Registration } \\
\text { Status }\end{array}$ \\
\hline 1 & $\begin{array}{l}\text { The Election Of } \\
\text { West Java } \\
\text { Governor } \\
\text { And Deputy } \\
\text { Governor }\end{array}$ & $\begin{array}{c}\text { Ridwan } \\
\text { Kamil }\end{array}$ & $\begin{array}{c}\text { Uu } \\
\text { Ruhzanul } \\
\text { Ulum }\end{array}$ & $\begin{array}{l}\text { 1. NASDEM } \\
\text { 2. PKB } \\
\text { 3. PPP } \\
\text { 4. HANURA }\end{array}$ & APPROVED \\
\hline 2 & $\begin{array}{l}\text { The Election Of } \\
\text { West Java } \\
\text { Governor } \\
\text { And Deputy } \\
\text { Governor }\end{array}$ & $\begin{array}{c}\text { Tubagus } \\
\text { Hasanuddin }\end{array}$ & $\begin{array}{l}\text { Anton } \\
\text { Charliyan }\end{array}$ & 1. PDIP & APPROVED \\
\hline 3 & $\begin{array}{l}\text { The Election Of } \\
\text { West Java } \\
\text { Governor } \\
\text { And Deputy } \\
\text { Governor }\end{array}$ & Sudrajat & $\begin{array}{l}\text { Ahmad } \\
\text { Syaikhu }\end{array}$ & $\begin{array}{l}\text { 1. GERINDRA } \\
\text { 2. PKS } \\
\text { 3. PAN }\end{array}$ & APPROVED \\
\hline 4 & $\begin{array}{l}\text { The Election Of } \\
\text { West Java } \\
\text { Governor } \\
\text { And Deputy } \\
\text { Governor }\end{array}$ & $\begin{array}{l}\text { Deddy } \\
\text { Mizwar }\end{array}$ & $\begin{array}{c}\text { Dedi } \\
\text { Mulyadi }\end{array}$ & $\begin{array}{l}\text { 1. GOLKAR } \\
\text { 2. DEMOKRAT }\end{array}$ & APPROVED \\
\hline
\end{tabular}

Source: The General Election Commission (2018)

This study begins with the initial findings (December 2017 period) of the 2018 West Java Governor Election Preparation that Deddy Mizwar and Dedi Mulyadi have decided to run in the election of the Governor and Deputy Governor of West Java 2018 on Tuesday 9 January 2018 at the General Election Commission (KPU) office West Java Jalan Garut, Bandung City. The next finding is the result of a survey conducted by Cyrus Network on January 16-22 2018 with 1,000 respondents distributed proportionally in 27 districts / cities in West Java. 
Table 2.

Data Report on Personal Popularity Level of Governor and Deputy Governor Candidates of West Java in 2018

\begin{tabular}{lll}
\hline No & Personal Popularity Level & Percentage \\
\hline 1 & Deddy Mizwar & $97.5 \%$ \\
2 & Dedi Mulyadi & $61.6 \%$ \\
3 & Ridwan Kamil & $78.8 \%$ \\
4 & Uu Ruzhanul Ulum & $33.3 \%$ \\
5 & Sudrajat & $21.0 \%$ \\
6 & Ahmad Syaikhu & $21.6 \%$ \\
7 & Tubagus Hasanuddin & $18.2 \%$ \\
8 & Anton Charliyan & $19.2 \%$ \\
\hline Source : Cyrus Network (2018)
\end{tabular}

The popularity level of Deddy Mizwar was $97.5 \%$, followed by Ridwan Kamil as much as $78.8 \%$ and Dedi Mulyadi was third at $61.6 \%$. From the level of popularity Deddy Mizwar has the highest level of popularity from its competitors which is due to one of them because Deddy Mizwar has also been known for a long time as a film actor.

Subsequent and proven findings in the survey results of several survey institutions are head to head between the Governor and Vice Governor's pair of pairs, Deddy Mizwar-Dedi Mulyadi and Ridwan Kamil-Uu Ruzhanul Ulum, for the profile and achievements of Ridwan Kamil and Uu Ruzhanul Ulum, in short RINDU by the Community, is quite difficult to resist in terms of electability especially Ridwan Kamil who has the highest personal electability.

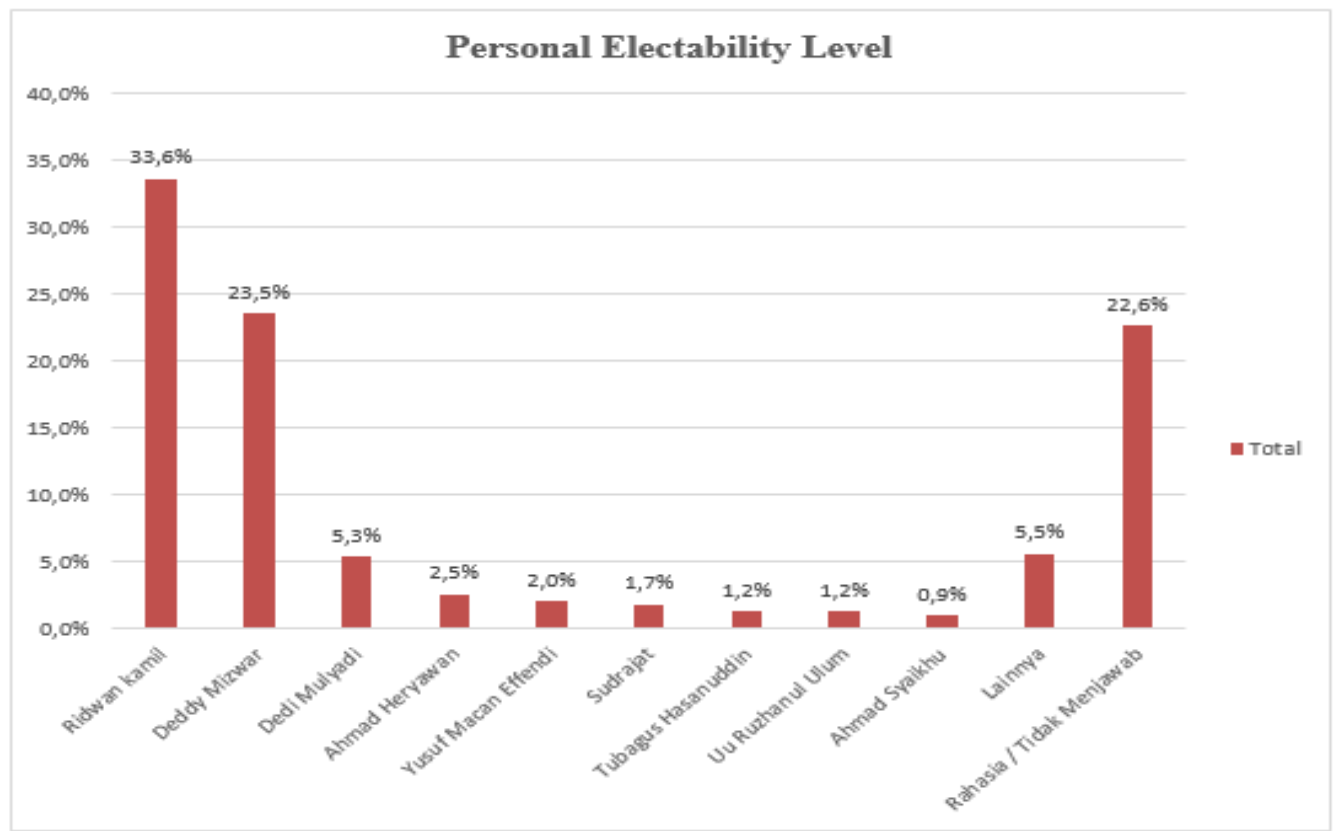

Source : Cyrus Network (2018)

\section{Graph 1.}

Personal Electability Level ofGovernor and Deputy Governor Candidates of West Java in 2018

Futher finding was Isentia Jakarta General Manager, Luciana Budiman, found that the results of Ridwan Kamil occupy the most positions discussed by Indonesian cyber citizens, in the monitoring period of May 1-July 30, 2017. 


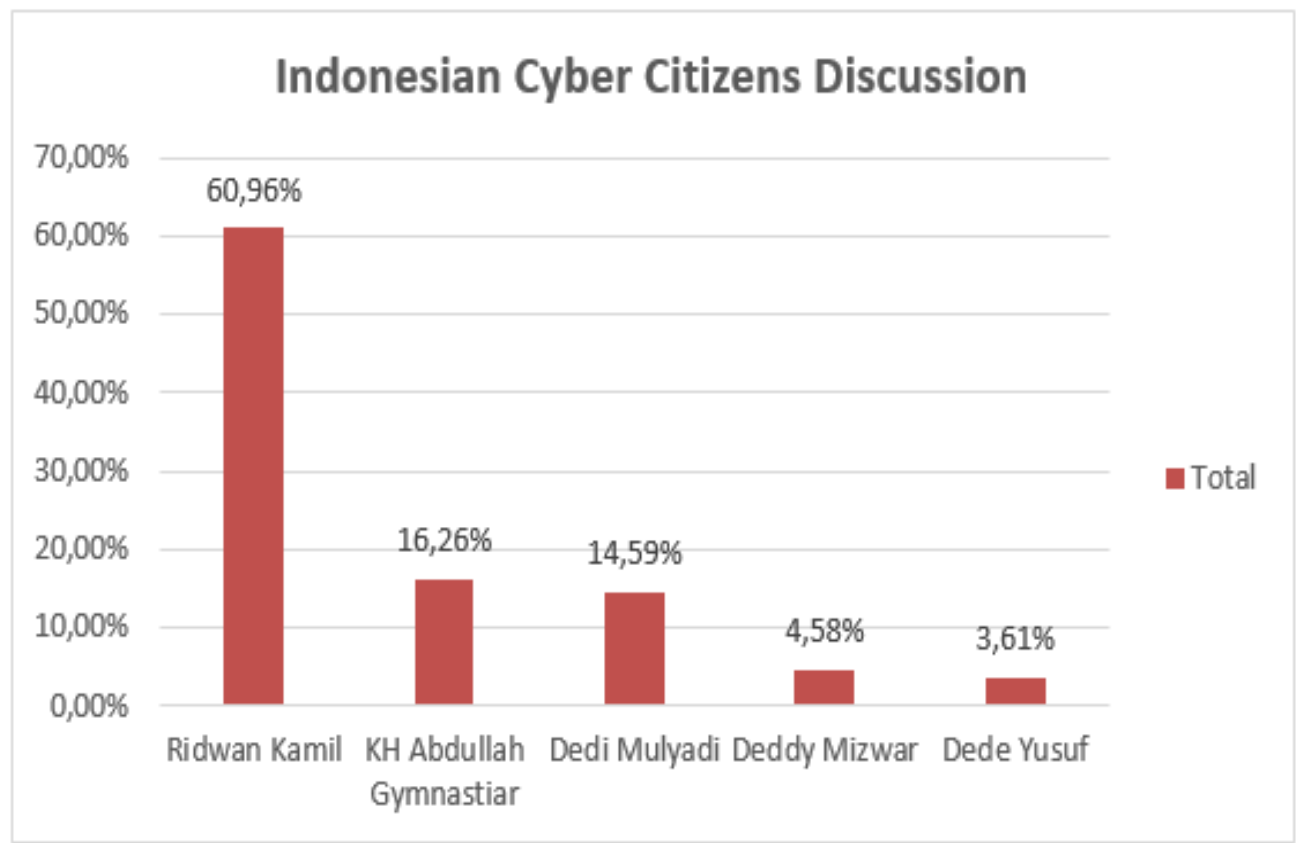

Source : Media intelligence company based in Australia, Insentia (2018)

Graph 2. Indonesian Cyber Citizens Discussion

The following findings were obtained from the results of several survey institutions in Indonesia in terms of the Electability of Election of Candidates for Governor and Deputy Governor of West Java 2018.

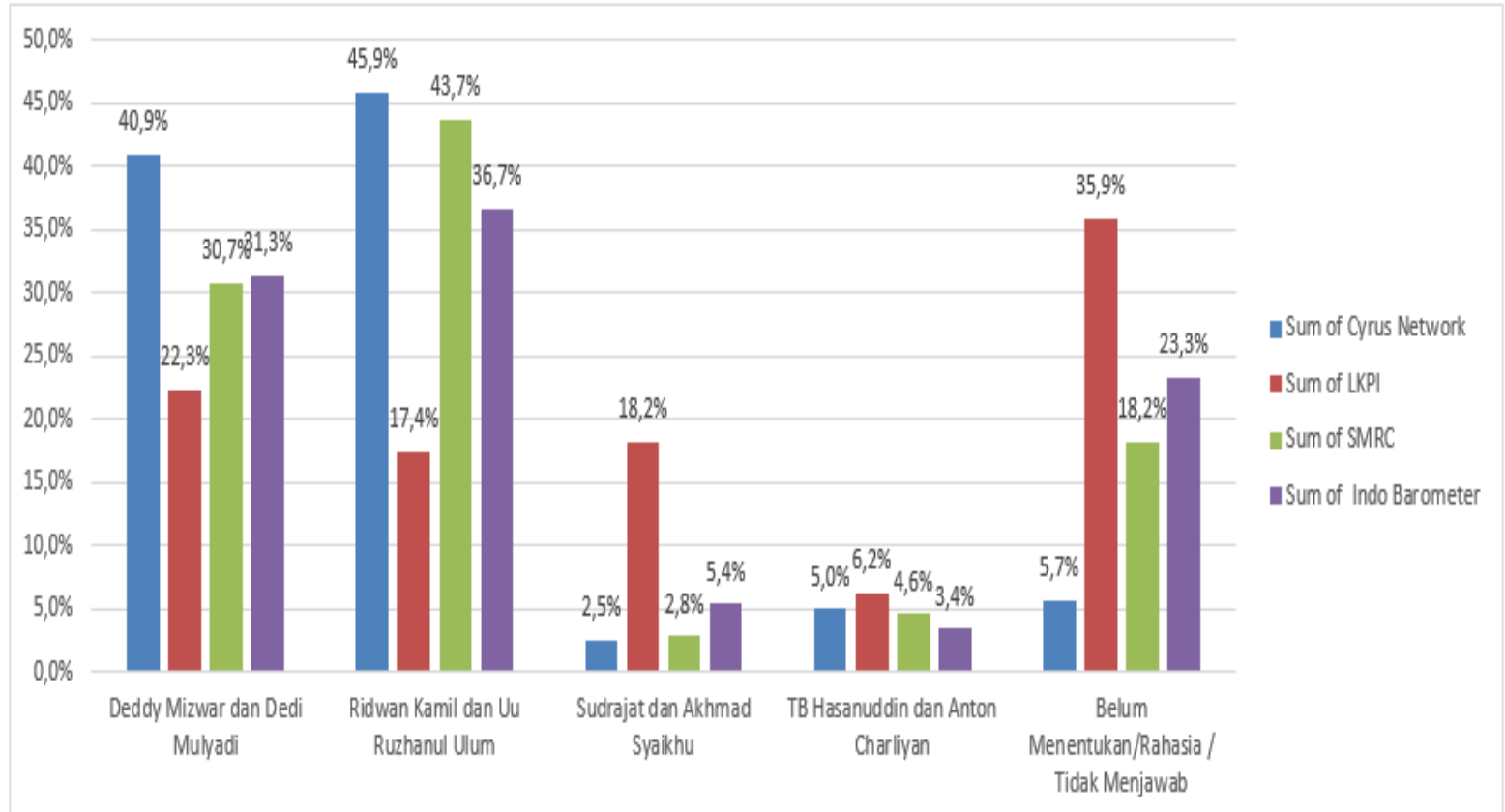

Source : Survey Institute Cyrus Network, Lembaga Konsultan Politik Indonesia, Saiful Mujani Research \& Consulting and Indo Barometer (2018)

Graph 3. Electability Survey Results of The Governor and Deputy Governor

\section{Candidates for West Java 2018}

Deddy Mizwar partnered with Dedi Mulyadi to advance electability. It proved the electability of the pair increased. 


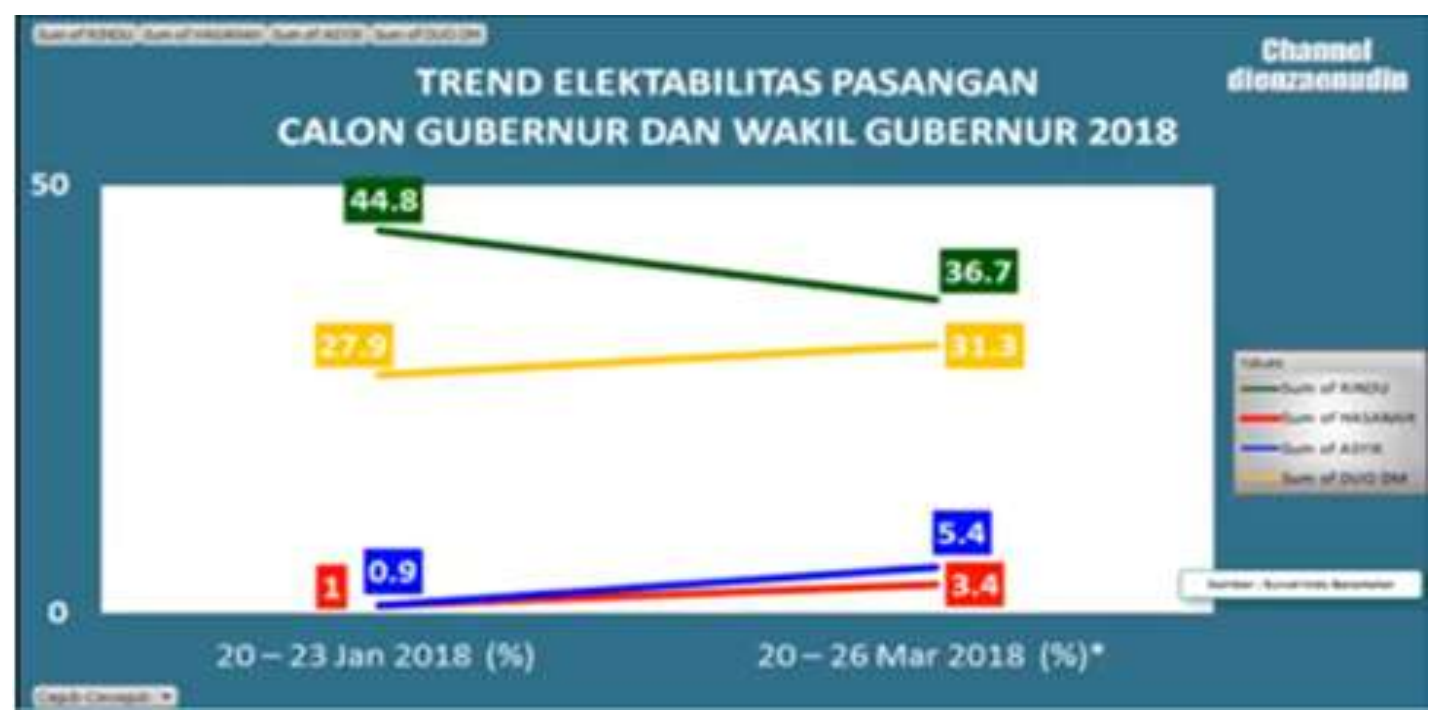

Source : Survey Institute Indo Barometer (2018)

Figure 1. Electability Trends of West Java Governor and Deputy Governor Candidates 2018

Indo Barometer Survey Institute stated that after Ridwan Kamil joined Uu Ruzhanul Ulum, the electability level decreased. On the contrary for Deddy Mizwar and Dedi Mulyadi actually increased because, indeed, Dedi Mulyadi was also well known to the community, especially in West Java.

The existence of the media today also has an immensely big role in influencing the community both in the city and regions.

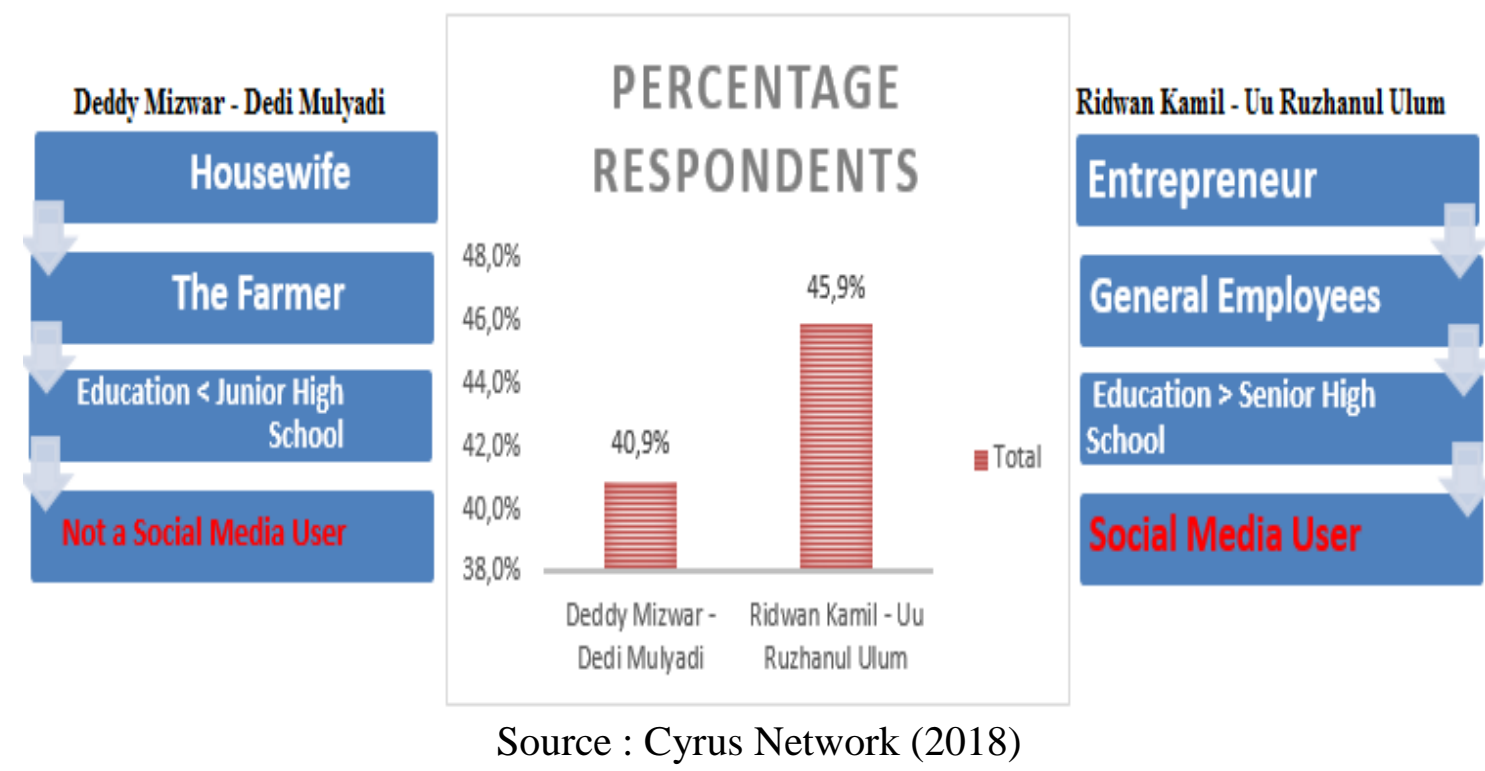

\section{Graph 4. Percentage of West Java Governor Election Respondents 2018}

In Graph 4 explained the comparison of the percentage and the number of respondents who won Ridwan Kamil more because he has long been involved in social media, has long published his performance as Mayor of Bandung, and it is proved that Ridwan Kamil was successful in using his strategy on social media. And this will cause Ridwan Kamil to get votes from millennial generation and certainly will be a problem for his opponents who are advancing in the 2018 West Java Governor Election. 
The simultaneous local elections were held on Wednesday, 27 June 2018. The results of the quick calculation were carried out by several survey institutions which featured Ridwan Kamil-Uu Ruzhanul Ulum's candidate who got the most votes thus giving an absolute victory over the pair, with the following calculation data from several survey institutions:

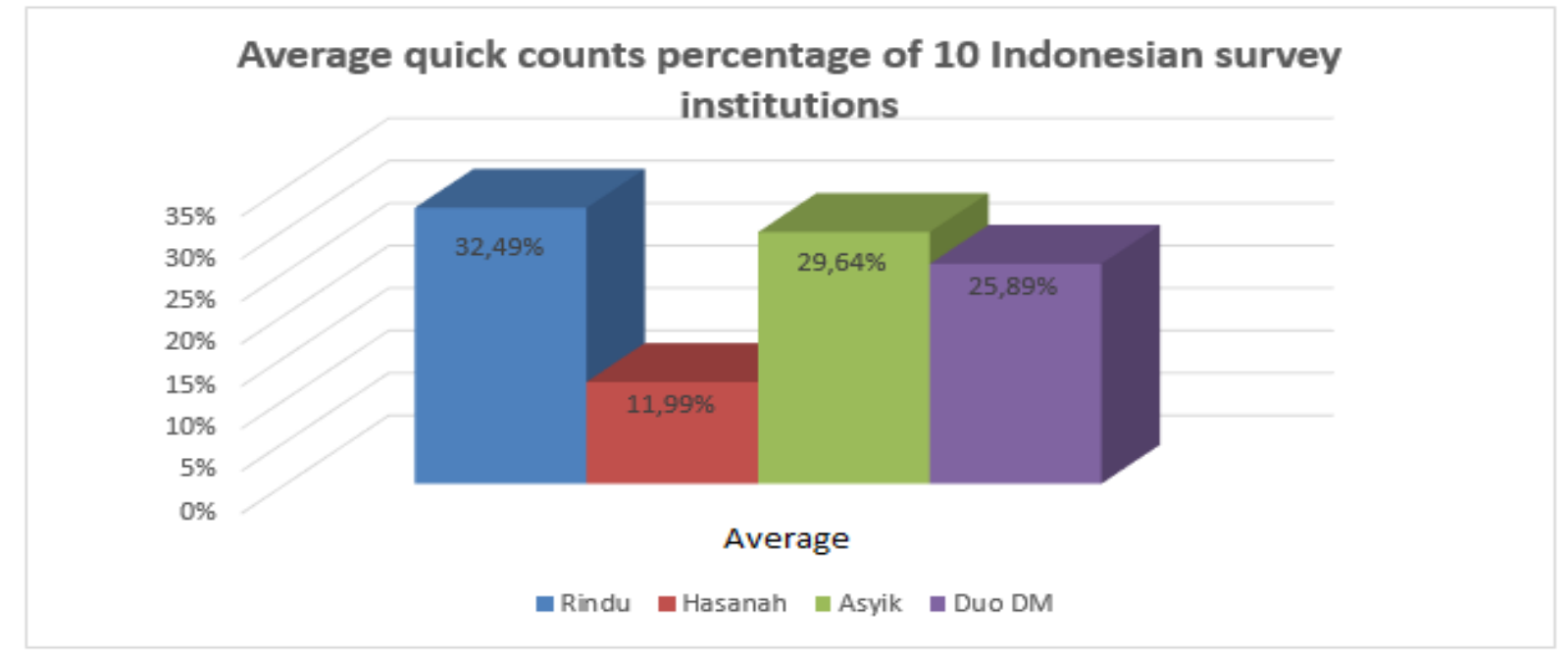

Source : LSI Denny JA, Populi Center, SMRC, Charta Politika, Litbang Kompas, Indo Barometer, Indonesia Development Monitoring, Indikator Politik Indonesia, LKPI, Poltracking Indonesia (2018)

Graph 5. Average quick counts percentage of 10 Indonesian survey institutions

If it is correlated, the phenomenon of the findings confirms some of the results of the survey institute, clearly states that Ridwan Kamil was elected Governor of West Java in 2018 and became the top of mind among other governor candidates such as Deddy Mizwar, TB Hasanuddin and Sudrajat. Need to think of a striking strategy to defeat Ridwan Kamil.

\section{LITERATURE REVIEW}

\section{Personal branding}

Is the process of forming people's perception of aspects owned by someone, among them are personality, abilities, or values, and how they all deliver positive perceptions from the community which can ultimately be used as marketing tools (Haroen, 2014; 13). According to Haroen (2014) in his book saying both theory and practice, a number of people in this world concluded that personal branding is very positive for one's success on the political stage.

The most fundamental thing in strong personal branding according to McNally \& Speak in Haroen (2014) is,

1. Characteristic

A strong personal brand describes something that is very specific or unique so that it is different from most people. Characteristics here can be represented by personal qualities, physical appearance, or expertise. 
2. Relevance

A strong personal brand explains something that is considered important by the community and has relevance to the character of that person. If this relevance is absent, it will be difficult to reinforce people's thinking.

3. Consistency

A strong personal brand is the result of consistent branding efforts in various ways so that brand equity is formed.

\section{Political Marketing}

According to Firmanzah (2008) political marketing is the application of marketing concepts and methods to politics. Marketing is needed to face competition in fighting over the market, which in this case is the voter. O'Shaughnessy in Firmanzah (2008), argues that political marketing is not a concept to "sell" political parties or candidates, but a concept that offers how a political party or a candidate can create programs that deal with actual problems.

According to Firmanzah (2008), in the Political Marketing process, 4P marketing integration is used, namely:

1. Product means party, candidate and party ideas that will be conveyed by constituents. This product contains concepts, ideological identity. Both past and present have contributed to the formation of a political product.

2. Promotion is the effort of advertising, public relations and promotion for a party that is combined in such a way according to the needs of the community. In this case, media selection needs to be considered.

3. Prices, including many things, starting from the economic, psychological, national image. Economic price includes all costs incurred by the party during the campaign period. Psychological price refers to psychological perception, for example, voters feel comfortable, with ethnic background, religion, education and others. Whereas the price of national image is related to whether voters feel that the candidate can give a positive image and can be the pride of the country.

4. Placement is closely related to the presence or distribution of a party and its ability to communicate with voters. This means that a party must be able to map the structure and characteristics of society both geographically and demographically.

\section{Politic of Identity}

According to Sari (2016) there are various perspectives when looking at the phenomenon of politic of identity. According to Bergh and Abdilah in Sari (2016) describe three theoretical perspectives in the study of politic of identity, namely: primordialism, constructivism, and instrumentalism. In Indonesia, politic of identity is more related to issues of ethnicity, religion, ideology, and local interests that are represented generally by the elite with their respective articulations. 


\section{Social Media}

According to Mandibergh in Nasrullah (2015) social media is media that accommodates collaboration between users that produce content (user-generated content. According to Djik in Nasrullah (2015) social media is a media platform that focuses on the existence of users who facilitate them in their activities and collaborations. Nugroho et al. (2015) describe social media has made it possible for one person to communicate with hundreds or even thousands of other people about products and the companies. The content, timing, and frequency of the social mediabased conversations occurring between consumers are outside managers' direct control.

According to Sulistyo (2016), the existence of online media in the middle of the community was considered to bring very significant impact, or in other words, the internet has brought asignificant effect to the users or to the audience, not the exception among teenagers. Therefore, social media can be seen as an online medium (facilitator) that makes the relationship between users become tight as well as a social bond. According to Bruhn in Coal (2017), namely: (1) media attractiveness; (2) media clarity; (3) complete media information; and (4) accessing media easily are indicators of social media.

\section{The Significance of Study}

To find out, whether, Personal Branding, Political Marketing, Politic of Identity and Social Media have positive and significant influence on the decision to choose Deddy Mizwar as Governor of West Java 2018. This writing is expected to make new contributions about the reality of Political Marketing in Indonesia and can provide benefits in the development of marketing science as reference material. This writing is also expected to be useful for candidates to maximize personal branding of the candidate himself, determine the Political Marketing strategy, and make use of new media, namely Social Media, which is used to interact with the community to be closer and forming a positive image.

\section{RESEARCH METHODS}

According to Yusuf (2014), scientific research is simply an activity carried out systematically, objectively, and logically by controlling or without controlling various aspects or variables contained in the phenomena, events, or facts under study in order to answer the question or problem being investigated. The method in this research is structural equation modeling. According to Wijanto in Pandhega et al. (2016) there are guidelines that the number of respondents needed in this study is five times of all variables observed in the research model. This study has 41 variables observed from the 5 constructs so that the minimum number of respondents needed is 205 people ( $41 \times 5)$.

Data collection by survey or questionnaire is carried out in its implementation. A purposive sampling technique was used. According to Diposumarto in Widyananto and Nurmahdi (2014), purposive sampling is a sample taken with certain requirements and for specified purposes. Everything must lead to specific goals, namely; 1 . He has chosen Deddy Mizwar as Governor in the election of the 2018 for West Java. 2. He is in the research area and can be a sample with a predetermined ratio. 
According to Katidjan et al. (2017) the Likert scale classification uses 5 scales, namely Strongly Agree (5), Agree (4), Hesitate (3), Disagree (2), and Strongly Disagree (1). The unit of analysis examined is individuals, namely individuals who have participated in the election, which will be represented by the community in 5 cities (Bekasi, Bandung, Tasikmalaya, Bogor, Depok) and 1 Regency (Garut) which respectively each participated as many as 36 respondents.

Table 3.

\section{Respondent Characteristics Based On Age}

\begin{tabular}{|c|c|c|}
\hline Age & Frequency & Percentage (\%) \\
\hline $17-25$ & 38 & $17,59 \%$ \\
\hline $26-35$ & 123 & $56,94 \%$ \\
\hline$>36$ & 55 & $25,46 \%$ \\
\hline Total & 216 & $100 \%$ \\
\hline
\end{tabular}

Source: Questionnaire data 2018

From Table 3 this can be understood considering that at that age he already knew the figure of Deddy Mizwar and was active in social media.

\section{RESULTS AND DISCUSSION}

The method of analysis in this study uses Component or Variance Based Structural Equation Modeling where data processing uses the Partial Least Square program (SmartPLS). PLS is an alternative model of SEM-based covariance (Ghozali, 2014). The purpose of PLS is to look for optimal predictive linear related the data.

Table 4.

Composite Reliability and Croncbach Alpha Test Results

\begin{tabular}{llll}
\hline \multicolumn{1}{c}{ Variable } & \multicolumn{1}{c}{$\begin{array}{c}\text { Croncbach's } \\
\text { Alpha }\end{array}$} & $\begin{array}{c}\text { Composite } \\
\text { Reliability }\end{array}$ & \multicolumn{1}{c}{ Detail } \\
\hline Personal branding (X1) & 0,910 & 0,926 & Reliable \\
Political Marketing (X2) & 0.935 & 0.944 & Reliable \\
Politic of Identity (X3) & 0,882 & 0,911 & Reliable \\
Social Media (X4) & 0,851 & 0,900 & Reliable \\
Decision to choose (Y) & 0.942 & 0.952 & Reliable \\
\hline
\end{tabular}

Source: PLS 3.0 2018

Based on Table 4 it can be seen that the value of Composite Reliability and Croncbach Alpha have fulfilled the requirements of $>0.7$ so that it can be said that the Personal Branding, Political Marketing, Political of Identity, Social Media and Decision Choosing variables are considered reliable to measure the unit of analysis that is being observed.

Table 5.

\section{R-Square Adjusted Results}

\begin{tabular}{cc}
\hline Variable & R-square Adjusted \\
\hline $\operatorname{Decision}$ to choose (Y) & 0,873
\end{tabular}

Source: PLS 3.02018 
R-square value Adjusted variable for Decision to Choose is 0.873 which means that Personal Branding, Political Marketing, Political of Identity, Social Media variables influence the Decision to Choose $87.3 \%$ while $12.7 \%$ is influenced by other variables that are not examined in this study.

Table 6.

Hypothesis Test Results

\begin{tabular}{llll}
\hline Hypothesis & $\begin{array}{c}\text { Original } \\
\text { Sample (O) }\end{array}$ & $\begin{array}{c}\text { T Statistic } \\
(\text { Io/STDEVI) }\end{array}$ & \multicolumn{1}{c}{ Details } \\
\hline H1 & 0.123 & 1,479 & Positive-Insignificant \\
H2 & 0.424 & 4,268 & Positive-Significant \\
H3 & 0,415 & 4,973 & Positive-Significant \\
H4 & 0,058 & 0,845 & Positive-Insignificant \\
\hline
\end{tabular}

Source: PLS 3.0 2018

Based on Table 6 the H1 hypothesis, it can be seen that the correlation between Personal Branding and Decision to choose is not significant but reveals the direction of the relation between them is positive. The Characteristic, Relevancy and Consistency of Deddy Mizwar are important factors, the reason for the community to decide on choosing Deddy Mizwar as Governor of West Java 2018. Therefore, these aspects must continue to be carried out and developed so that they will attract public attention.

In the $\mathrm{H} 2$ hypothesis in Table 6 shows the relation between Political Marketing and Decision to choose is significant and disclose the direction both of them is positive. Product, Price, Promotion and Place aspects are important factors as well where a good marketing strategy will impact the increasing number of people who will give their voting rights to Deddy Mizwar.

The hypothesis H3 in Table 6 shows that the relation between Political of Identity and Decision to choose is significant and the direction is positive as well. The aspects of Primordialism, Constructivism and Instrumentalism are also determinants for the community in determining their voting rights to Deddy Mizwar.

Hypothesis H4 shows the relation between Social Media and Decision to choose is not significant yet shows the direction of the relation between them is positive. Aspects of Media Attractiveness, Media Clarity, Completeness of Media Information and Easy Media Access are included as important factors as well in creating one's decision to choose a leader, especially a Governor of West Java. Which now the role of social media is substantial to be applied to reach the community quickly and easily, but there are also certain circles that cannot be reached by social media such as farmers or people who are less familiar with technology.

\section{CONCLUSION AND SUGESTION}

This research is expected can achieve academic and practitioner significance. Therefore, some suggestions are given as follows:

Based on the results of research on Personal Branding variables get the lowest MEAN value on the statement "Dedi Mizwar can solve various problems from the community" 
which according to respondents, that regional head must be able to solve all the problems that exist in society and should've been proven, especially for the people of West Java.

Based on the results of research on Personal Branding variables get the lowest MEAN value on the statement "Deddy Mizwar can make people accept every policy he has." Which according to respondents that a regional head candidate is expected to have a policy that can be in line with current conditions, especially in the community of West Java.

Based on research results the Political of Identity variable gets the lowest MEAN value at the statement "I give credence to West Java community solidarity to support Deddy Mizwar ". Which the respondents think did not choose because of a sense of solidarity, but because it was based on their own desires. So it is recommended to be more sociable to all communities and non-governmental organizations and other organizations that can solidify the solidarity of West Java citizens.

Based on research results the Social media variable gets the lowest MEAN value in the statement "Deddy Mizwar often actively communicates on social media to the people of West Java". Which according to respondents that regional head candidates must be more active in Social Media, because according to the current industry era, Social Media can be used as a media to carry out campaigns in conveying ideas and work programs so that it can become viral in the community.

Based on the research results on the decision variable to get the lowest MEAN value on the statement "People easily get services from Deddy Mizwar". Which respondent thinks that the head of region candidate must be able to provide good services to the community and has also been proven to the community so far, especially services that have been already received by the people of West Java.

Based on the discussion and conclusions taken by the authors, the next research is recommended to use other research areas for regional selection. And it should be adding other variables also to enrich references to the behavior of political consumers so that they can explain what factors can influence the decision to choose in the regional head election.

\section{REFERENCE}

Batubara, R.M. 2017. "Pengaruh penggunaan media sosial dan transfer pengetahuan terhadap kinerja pegawai pemerintahan”. Jurnal Riset Sains Manajemen. Vol. 1 (1), pp: 55-66, ISSN 2597-4726.

BBC News. 2018. Ridwan Kamil dan Strategi Media Sosialnya: Kenapa Selalu Soal Jomblo?. [Online] Available: https://www.bbc.com/indonesia/trensosial-42319886 [May 15, 2018].

Firmanzah. 2008. Marketing Politik: Antara Pemahaman Dan Realitas. Yayasan Pustaka Obor Indonesia:Jakarta.

Garson, G.D. 2016. Partial Least Squares: Regression and Structural Equation Modals. Asheboro, Statistical Associates Publishers.tam: Nort Country.

Haroen, D. 2014. Personal Branding: Kunci Kesuksesan Berkiprah Di Dunia Politik. Gramedia Pustaka Utama: Jakarta.

Katidjan, P.S., Pawirosumarto, S., and Isnaryadi, A. 2017. "Pengaruh Kompensasi, 
Pengembangan Karir dan Komunikasi Terhadap Kinerja Karyawan”. Jurnal MIX: Jurnal Ilmiah Manajemen. Vol. VII, (3), pp:429-446.

Merdeka.com. 2017. Sering Main Media Sosial, Ridwan Kamil Mampu Pikat Generasi Milenial. [Online] Available: https://www.merdeka.com/politik/sering-main-mediasosial-ridwan-kamil-mampu-pikat-generasi-millenial.html. [May 15, 2018].

Nasrullah, R. 2015. Perspektif Komunikasi, Budaya, dan Sosioteknologi. Simbiosa Rekatama Media: Bandung.

Nugroho, A., Harwani, Y., Dewita, A., and Sihite, J. 2015. "Is it Traditional or Contemporary Marketing Strategy? A Textual Cluster Analysis @ MercuBuana_Reg”. Mediterranean Journal of Social Sciences. Vol. 6 (5 S5). ISSN 2039-9340.

Pandhega, S., Hati, S.R.H., Miranti, S. 2016. "Pengaruh Persepsi Merek Jasa Terhadap Service Quality, Value dan Loyalitas Pelanggan: Studi Industri Low Cost Airlines Indonesia”. Jurnal MIX: Jurnal Ilmiah Manajemen. Vol VI, (3) pp: 349-366.

Putri, Z, A,- detik News. 2018. Survei Cyrus: Ridwan Kamil-Uu 45,9\%, Duo DM 40,9\%. [Online] Available: https://news.detik.com/berita/3850954/survei-cyrus-ridwankamil-uu-459-duo-dm-409 [May 14, 2018].

Sari, E. 2016. "Kebangkitan Politik Identitas Islam Pada Arena Pemilihan Gubernur Jakarta”. Jurnal Ilmu Sosial dan Ilmu Politik.Vol 2 (2), ISSN 2460-3848.

Sulistyo, P.B. 2016. "Motive of Usage and Opinion Regarding the Impact of Online Media among Teenagers (Survey in City of Jakarta and bandung, Indonesia)”. International Journal of Scientific and Research Publications. Vol 6, Issue 9. ISSN 2250-3153.

TribunJabar.id. 2018. Naik Kuda, Duo DM Akan Daftar ke KPU Jabar Hari Ini. [Online] Available: http://jabar.tribunnews.com/2018/01/09/naik-kuda-duo-dm-akan-daftar-kekpu-jabar-hari-ini. [May 14, 2018].

Perludem. 2012. Undang-Undang Republik Indonesia No.15 2011 Tentang Penyelenggaraan Pemilihan Umum. [Online] Available: http://www.perludem.org/2012/02/09/undangundang-no-15-tahun-2011/. [May 14, 2018].

Widyananto, I.H., and Nurmahdi, A. 2014. “Analisis Pengaruh Kualitas Produk, Distribusi dan Pelayanan Purna Jual Terhadap Kepuasan Pelanggan Perusahaan Kemasan Plastik PT. Jayatama Selaras”. Jurnal MIX: Jurnal Ilmiah Manajemen. Vol IV (3), pp: 286-298.

Yusuf, M. 2017. Metode Penelitian (Kuantitatif, Kualitatif dan Penelitian Gabungan).(Edisi 1. Cetakan ke-4) Kencana: Jakarta.

Zainudin, D. 2018. 7 Lembaga Survei Elektabilitas Pasangan Cagub-Cawagub Di Pilgub Jabar 2018. [Online] Available: https://www.youtube.com/watch?v=1Fs29mhrI0Y\&t=74s. [May 16, 2018].

Zainudin, D. 2018. 9 Quick Count Lembaga Survei, Hitung Cepat Unggulkan Rindu dan Asyik di Pilgub Jabar 2018. [Online] Available: https://www.youtube.com/watch?v=vYjxV0MMxDs. [July 16, 2018].

Zainudin, D. 2018. Survei Cyrus Network Pilgub Jabar 2018 Elektabilitas Ridwan Kamil Popularitas Deddy Mizwar Tinggi. [Online] Available: https://www.youtube.com/watch?v=i5_yvmsnSQ\&t=457s. [May 16, 2018]. 